\title{
Can Venous Ulcer Size be Associated with the Healing Potential of Serum? Pilot Study
}

\author{
Melisa C Crocco $^{1^{*}}$, Diana M Kelmansky ${ }^{2}$, Roberto H Mengarelli ${ }^{3,4}$, Roberto Cherjovsky ${ }^{3,4}$, \\ Alicia G Fuchs ${ }^{1}$ \\ ${ }^{1}$ Centro de Altos Estudios en Ciencias Humanas y de la Salud, Universidad Abierta Interamericana (Center for \\ Advanced Studies in Human and Health Sciences, Inter american Open University), Buenos Aires, Argentina \\ ${ }^{2}$ Instituto de Cálculo, Facultad de Ciencias Exactas y Naturales, Universidad de Buenos Aires (Calculus \\ Institute, Faculty of Exact and Natural Sciences, University of Buenos Aires), Ciudad Universitaria, Pabellón \\ II, $2^{\circ}$ Piso, Buenos Aires (C1428EHA), Argentina \\ ${ }^{3}$ Facultad de Medicina, Universidad Abierta Inter americana (Faculty of Medicine, Inter american Open \\ University), Av. San Juan 951, 1014, Buenos Aires, Argentina \\ ${ }^{4}$ Grupo Interdisciplinario de Cicatrización de Heridas (GICICH), Universidad Abierta Interamericana \\ Interdisciplinary Wound-Healing Group, Inter american Open University), Buenos Aires, Argentina \\ *Corresponding Author: Melisa C Crocco, Centro de Altos Estudios en Ciencias Humanas y de la \\ Salud, Universidad Abierta Interamericana (Center for Advanced Studies in Human and Health Sciences, \\ Inter american Open University), Buenos Aires, Argentina, Email: melcrocco@yahoo.com
}

\begin{abstract}
Ulcer size may be associated to slow healing. If this association is true, it could help with diagnosis and subsequent treatment of chronic venous ulcer (CVU). The aim of this work was to study the relationship of ulcer size of CVU patients with the healing potential contained in their serum. This potential was measured directly on patients' sera through a cytometric technique for the content of Vascular Endothelial Growth Factor (VEGF) and Fibroblast Growth Factor (FGF). These factors are responsible for revascularization, fibroblast proliferation and collagen deposition. Further, the effect of serum on proliferation and collagen deposition was evaluated in vitro cultures.
\end{abstract}

The results of the in vitro experiment highlighted the isolated effects of homolateral venous serum factors on Vero cells line not undergoing any inflammation. Ulcer size did not influence the characteristics of sera from $C V U$ patients. In the discussion our results are evaluated in the context of recent research regarding ulcer sizes.

Keywords: $C V U$, ulcer size, serum, vegf, fgf, proliferation, collagen

\section{INTRODUCTION}

The prevalence of the venous ulcers in Latin America is estimated between 3 and $6 \%$ of the population [1]. In North America and Europe this prevalence is $0.2 \%$ [2]. Among LatinAmerican physicians, there is a consensus on the greater size of ulcers with respect to European and U.S. populations. Large sizes are attributed to lack of prevention, late consultation, delayed treatment and lack of resources. Although statistics are very scarce, this does not diminish its importance as a public health problem [1].

Chronic venous insufficiency is a multifactorial progressive disease that affects the functioning

ARC Journal of Dermatology of the venous muscular and valvular-parietal pumps. This valvular incompetence results in edema, induration, fibrosis, skin necrosis, and when a trauma happens a wound appears without tendency to closure. Chronic venous ulcer, results from an imbalance that keeps the wound in the inflammatory phase. The persistent inflammatory response and the unbalanced proteolytic activity overwhelm tissue protective mechanisms [3, 4].

During repair of the cutaneous tissue, Vascular Endothelial Growth Factor (VEGF) and Fibroblast Growth Factor (FGF) are responsible for revascularization, fibroblast proliferation and collagen deposition $[5,6]$. VEGF is an endothelial cell mitogen, with a 165-amino- 
acid-long variant representing the major isoform in human tissues. Fibroblasts synthesize and remodel the Extra Cellular Matrix (ECM; 7), and are considered the main producers of procollagen [8]. Collagen provides scaffolds for cellular attachment, migration, and proliferation in wound healing. Ulcer size and patient age may be associated to healing speed, moreover an ulceration surface greater than $20 \mathrm{~cm}^{2}$ is indicative of slow healing [37].If these associations are true, they could help with diagnosis and subsequent treatment.

The aim of this study was to evaluate the in vitro effect of serum from patients with CVU on the wound healing processes of proliferation and collagen deposition. Also VEGF and FGF content was evaluated by a cytometric technique directly on patients sera. The possible modifications of each of the following: proliferation, collagen deposition, VEGF and FGF, with ulcer size, wound duration and patient age were also addressed. We consider that this knowledge will contribute to the understanding of the pathogenesis of CVU.

\section{MATERIALS AND METHODS}

\subsection{Serum Samples}

This work was approved by the Bioethics Committee from Universidad Abierta Interamericana, Buenos Aires, Argentina. All patients signed a consent letter prior to their participation. The study was performed including only male patients with refractory venous wounds subjected to 6 months of treatment at the Hospital Municipal de Tigre Buenos Aires, Argentina, between June and December of 2013 evaluated by one physician (R.H.M.). Only male patients were considered to reduce variability due to estrogens, an important factor that would predispose to venous ulcers [38].The venous ulcer was determined by the clinical characteristics and by Eco Doppler (discarding arterial disease), corresponding to stage $\mathrm{C} 6$ active venous ulcer of CEAP (Clinico Etiologic Anatomic Pathologic). Blood from homolateral-to-ulcer femoral veins was obtained. Two weeks prior to blood extraction the studied patients were restricted of medication affecting hemodynamics (venotonics). This was the only intervention for both patients with and without co-morbid conditions (Table 1). All blood samples were tested for Chagas diseases, AIDS, hepatitis B and $\mathrm{C}$, and syphilis before use. The serum samples were blindly handled and inactivated in a water bath at $56^{\circ} \mathrm{C}$ for $20 \mathrm{~min}$ and frozen at - $20^{\circ} \mathrm{C}$ until use. As an experimental control, standardized sera from a pool of healthy men (Sigma Aldrich, H4522) were used.

\subsection{Flow Cytometry}

Vascular endothelial growth factor (VEGF-165) and basic fibroblast growth factor (bFGF) were measured using the Human Soluble Protein Flex Set Assay kit - Cytometer Bead Array (CBA; $\mathrm{BD}$, Pharmingen, CA, USA). Beads were read in a fluorescence-activated cell sorting equipment AriaII (LANAIS, Buenos Aires). Resultswere analyzed in BD CBA Analisys Software (BD Biosciences, Cat.No. 550065) obtaining mean fluorescence intensities.

\subsection{Cell Line Culture}

In vitro experiments with patient serum were performed on a Vero cell line of epithelial cells from African green monkey kidneys, obtained and certified from ABAC (Argentinean Cell Bank). Cells were routinely cultured in RPMI 1640 medium (Sigma, life technology) supplemented with $10 \%$ of inactivated fetal calf serum (FCS) (Notocord, Cordoba, Argentina), $1 \%$ penicilina-streptomycina (Sigma), $2 \mathrm{mM}$ glutamine (Sigma), and 0.37\% Hepes (Sigma). They were incubated at $37^{\circ} \mathrm{C}$ with $5 \% \mathrm{CO} 2$ (MCO-17AC incubator). After growing for 4 days ( $80 \%$ monolayer confluence), cells were trypsinized and then divided for performing the following two simultaneous experiments.

\section{a) Cell Proliferation}

Vero cells were incubated for $48 \mathrm{hrs}$ in 96multiwell plates at $6 \times 10^{4} \mathrm{cell} / \mathrm{ml}$, in medium with $2 \%$ FCS. They were then incubated for 72 $\mathrm{h}$ in medium with $1 \%$ of FCS according to the following treatments: either patient or standardized 5\% serum. Proliferation was measured by tetrazolium salt colorimetric assay (MTT; 9) in which $2.27 \mathrm{mg}$ of tetrazolium salt (Sigma) in $5 \mathrm{ml}$ of PBS was added to growing cultures and incubated for $1 \mathrm{~h}$ at $37^{\circ} \mathrm{C}$. The intracellular tetrazolium reactive was dissolved in DMSO (dimethylsufoxide) by shaking at 160 rpm. Colour was measured OD $560 \mathrm{~nm}$ with Glomax Multidetection System (Promega). Each treatment was performed in quadruplicate in each plate and this experiment was performed in three different plates.

\section{b) Collagen Deposition}

Vero cells were incubated for $48 \mathrm{~h}$ in 24multiwell plates at $4 \times 10^{4}$ cell/ $\mathrm{ml}$, in medium with $2 \%$ FCS. A 72-hour incubation was then performed according to cell proliferation 
guidelines. Cells were washed with PBS$100 \mathrm{mM}$ EDTA and they were lysed with Tris$\mathrm{HCl} \mathrm{pH}=8.5,1 \%$ SDS, and $1 \%$ triton $\mathrm{X} 100$, containing protease inhibitor $0.2 \% \mathrm{v} / \mathrm{v}$ (Sigma P8340-5). Protein concentration was measured by the Bradford method. A fixed protein amount from each well was then used for measuring total collagen content by Erlich's method. Briefly, proteins were incubated with $10 \mathrm{~N} \mathrm{HCl}$ at $90{ }^{\circ} \mathrm{C}$ overnight, a saturated solution of $\mathrm{NaCl}$ and $7 \%$ cloramine- $\mathrm{T}$ was added and further incubation took place with Erlhich reactive at 60 ${ }^{\circ} \mathrm{C}$ for $30 \mathrm{~min}$. Samples were measured by the Glomax Multidetection System (Promega). Absorbance of unknown samples was obtained from the standard curve of hydroxyprolin. Quadruplicate samples were evaluated.

\subsection{Statistical Analysis}

Values of patient serum effects on cell proliferation and collagen deposition were contrasted with those found in the standardized serum. Both proliferation and collagen values were compared using multiple regressions controlling for culture dish (i.e. inter experiments) and patient. For proliferation and collagen bar plots, patient values were expressed in percentages respect to the standardized sera samples (100\% for each plate, internal control). The relations amongst all the obtained experimental results with patient age, wound duration (as reported by the patient), and ulcer size (Table 1) were studied with Wilcoxon test and regression analysis. The previously described analyses were performed using the $\mathrm{R}$ software [10].

Table1: Features of patient and ulcers

\begin{tabular}{|l|l|l|l|}
\hline $\begin{array}{l}\text { Extending } \\
\text { higher } \\
\text { ulcer(cm }\end{array}$ & $\begin{array}{l}\text { Age } \\
\text { (years) }\end{array}$ & $\begin{array}{l}\text { Evolution } \\
\text { time } \\
\text { (months) }\end{array}$ & Comorbidities \\
\hline 9 & 72 & 12 & HT - CPOD \\
\hline $25 \mathrm{a}$ & 73 & 24 & - \\
\hline $25 \mathrm{~b}$ & 90 & 15 & - \\
\hline 30 & 77 & 6 & $\begin{array}{l}\text { HT- } \\
\text { Diverticular } \\
\text { disease }\end{array}$ \\
\hline 50 & 59 & 6 & $\begin{array}{l}\text { HT- } \\
\text { Lymphedema }\end{array}$ \\
\hline 80 & 60 & 30 & PS \\
\hline 150 & 64 & 40 & - \\
\hline 200 & 73 & 15 & PS \\
\hline 200 & 67 & 36 & $\begin{array}{l}\text { HT- Diabetes- } \\
\text { PS }\end{array}$ \\
\hline 210 & 67 & 17 & $\begin{array}{l}\text { Orthopedic } \\
\text { surgery }\end{array}$ \\
\hline 225 & 67 & 42 & - \\
\hline 450 & 74 & 46 & $\begin{array}{l}\text { HT- } \\
\text { Arrhythmia }\end{array}$ \\
\hline
\end{tabular}

Patients sorted by total area (size) of the ulcer. Hypertension (HT); Chronic pulmonary obstructive disease (CPOD); Posthrombotic syndrome (PS)

\section{RESUlTS}

\subsection{Content of Growth Factors in Sera from Patients in a Wide Range of Ulcer Sizes}

Sera from patients with CVU presented VEGF165 (named VEGF) content between 22.5 and $250.54 \mathrm{pg} / \mathrm{ml}$. Ulcers with higher VEGF contents corresponded to both small and large sizes ( 25 and $225 \mathrm{~cm}^{2}$ respectively), while lower contents of VEGF were found in intermediate sizes $\left(50-150 \mathrm{~cm}^{2}\right)$ within the range studied (9$450 \mathrm{~cm}^{2}$ ). Neither ulcer size nor wound duration nor patient age (mean 70.2 years old, range 59 90 , Table 1) were associated with an increase of serum VEGF content. No detectable amounts of bFGF were found, this is, patients' serum levels were below the equipments threshold $(9 \mathrm{pg} / \mathrm{ml})$.

\subsection{Effects of Sera from Patients with a Wide Range of Ulcer Sizes on In-Vitro Cultures \\ a) Cell Proliferation}

Vero cells incubated with patient sera $(n=10)$ showed proliferation that was significant when compared with cells incubated with the standardized serum $(\mathrm{p}<0.00001)$. However, this result does not correspond to a comparison between similar, aged-matched healthy individuals. The proliferative effect was very clear in 7 of 10 patient sera (Fig. 2). When proliferation was compared to ulcer size, wound duration, patient age, VEGF content and collagen deposition, no associations were found.

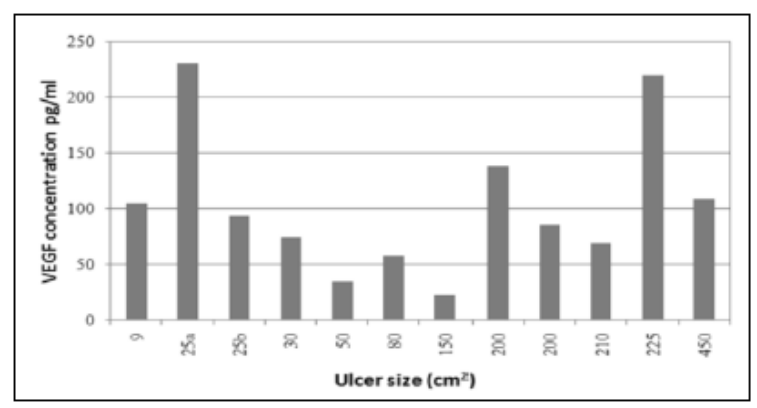

Figure1: VEGF content in sera from patients with $C V U$

In the $\mathrm{X}$ axis patients are ordered according to ulcer size.

\section{b) Collagen Deposition}

The hydroxyproline content of Vero cells cultured with patie nt serum was not incremented in respect to standardized serum (patient mean 16.76 \pm sd $10.31 \mathrm{ug} / \mathrm{ml}$; standardized serum mean $19.35 \pm$ sd 10.53 $\mathrm{ug} / \mathrm{ml}$ ). Moreover, it was reduced in 7 of 12 
patients( $p=0.07$, Sign test; Fig 2$)$. Neither ulcer size nor patient age nor wound duration was associated with a collagen deposition.

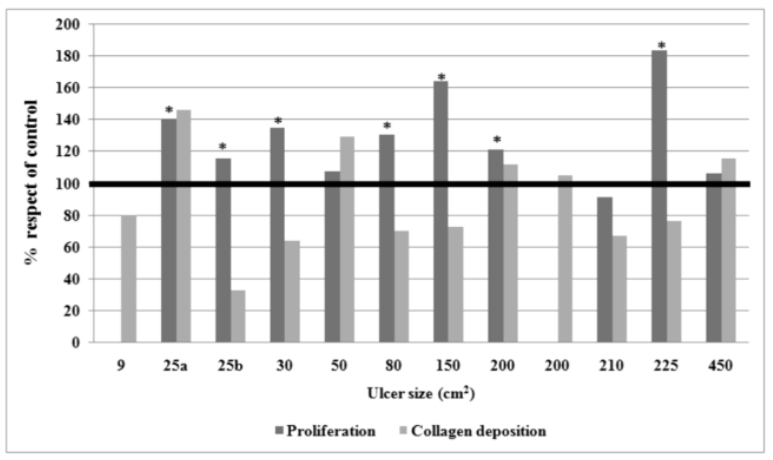

Figure2: Effects of patient sera on proliferation and collagen deposition

For each patient the bars show the ratio of Vero cell proliferation and collagen deposition produced with patient serum respect to standardized serum (100\%). Bars not seen result from missing determinations. Asterisks indicate significant proliferation when compared with cells incubated with the standardized serum ( $\mathrm{p}<$ 0.00001).

\section{DISCUSSION}

It is estimated that $2 \%$ of the world population will develop an ulcer at some point in their lives. The typical feature of chronic wounds $(\mathrm{CW})$ is the absence of the granulation tissue that could cover the wound area, restoring tissue integrity [11]. This work shows the isolated effect of serum factors from CVU patients on an epithelial cell line not undergoing any inflammation. This in vitro model avoids the effect of healing on the studied factor function.

In acute wounds, VEGF is up regulated to promote early stages of angiogenesis, and levels remain elevated until epidermal coverage is complete (12). In fluids of chronic leg ulcers, the expression of VEGF-165 and VEGF receptors is up regulated compared with fluids of uninjured skin of healthy individuals [13, 14]. In the present work the amount of seric VEGF165 was higher than in standardized sera from healthy patients, resembling the results previously mentioned for fluid levels.

Plasma levels of VEGF in chronic venous disease have been measured in only a few studies [15, 16]. Howlader and Smith(2004) reported higher VEGF levels in patients with C2 to $\mathrm{C} 5$ clinical stages in comparison to controls, and showed that statistical significance was only reached in those with healed ulceration (C5). For active venous ulcer patients (C6) with sizes up to $142.4 \mathrm{~cm}^{2}$, the VEGF median level was $165 \mathrm{pg} / \mathrm{ml}$ (range $21-1315 ; 18$ ). The results of the present research provide a first report of the seric VEGF content in very large active ulcers of up to $450 \mathrm{~cm}^{2}$ : median $90 \mathrm{pg} / \mathrm{ml}$ (IQR 66 to 116; range 22.5-229.6). These values are within the range previously described [18]. Both studies support the idea that ulcer size and serum VEGF levels are not related.

In this study we have seen that the cell line behaves differently when incubated in the presence of patient sera or human standardized serum. The observed proliferative effect of sera from patients with CVU indicates the presence of stimulating factors and its potential in tissue formation and wound closure. Since the major proliferative factors stimulating the epithelial cells in CW are epidermal growth factor (EGF; 19) and keratinocyte growth factor (KGF;12), it would be interesting to focus on those factors in future studies.

The results mentioned above indicate that there is an increase of an angiogenic factor (VEGF) and cell proliferation. Both seem to enhance healing capacity. However, it is possible that healing is impaired due to the tissue environment, which is rich in immune cells, proteases and oxidants that cause early breakdown of collagen and growth factors $[3,13,20]$. Furthermore, the chronic venous wounds would lead to defective angiogenesis and this could also prevent healing. Likewise, it would be valuable to study whether the increment of VEGF in CVU patients favors or not wound healing.

In acute wounds, bFGF shows initially elevated levels, just as a stimulus for angiogenesis, and then declines and remains low (while VEGF remains elevated) until the wound is granulated [6]. In CW, concentrations of bFGF were not detected in serum samples [18]. This agrees with the results of the present study where bFGF was below the detection threshold of the equipment. The observed increased content of serum VEGF along with low levels of serum bFGF matches with inflammatory phase detention expected for this kind of ulcers.

Deficiencies of collagen in CW tissues can be explained by many factors. Oxygen tension is usually below $40 \mathrm{mmHg}$, causing delay in the hydroxylation of proline and lysine and in subsequent collagen production [19]. Also, the accumulation of degraded collagen in the ECM could inhibit type I procollagen synthesis [21, $22,23]$. Finally, fibroblast senescence is 
implicated in the wound chronicity $[24,25,26$, 27]. Senescent fibroblasts exhibit an ECM degradative phenotype and down regulate the type I collagen [28]. Moreover, transforming growth factor- $\beta$ (TGF-b) is the most potent inducer of procollagen I gene expression identified in fibroblasts [27, 28, 29]. In CW tissues, the expression of TGF-b and its receptors is reduced with respect to acute wounds $[30,31]$. This reduction could be due to the capture [32] or degradation by proteolytic enzymes [33]. In addition, the present study indicates that systemic causes for limited collagen deposition could be possible given that patient serum impaired normal deposition in Vero cells. At the tissue level, the low collagen content is reflected in the ulcer low ECM support for migration, proliferation and healing.

With regard to age, wound healing in healthy older people includes delayed angiogenesis and slower epithelialization [36]. It is possible that the range we have studied (59 to 90), which is biased towards higher ages, is not large enough to uncover age differences in VEGF content, proliferative effect or collagen deposition.

For Franks et al (1995, [39]) and Margolis et al (1999, [40]), wound size (on ulcers smaller than $30 \mathrm{~cm}^{2}$ ) and wound duration were strong risk factors for the failure of venous leg ulcers to heal. They also studied diabetes mellitus, hypertension and deep vein thrombosis, and found they were not associated with failure of wound healing. A more recent work with comparable ulcer sizes [34], corroborates that the area is associated with non-healing. Moreover in Margolis' work (1999, [40]), the effect of wound duration on non-healing depends on wound area and vice versa. Margolis concludes that "the risk of not healing initially increases rapidly for patients with large and old wounds, but the magnitude of the increased risk diminishes with the largest and oldest wounds". In our study, most ulcers' sizes were beyond the largest ulcers described by Margolis (27.31 $\mathrm{cm}^{2}$ ). It is possible that in this context the risk of not healing, no longer increases with size. Therefore, healing no longer depends on this factor. In this sense, another recent retrospective study [35] with ulcers up to nearly $300 \mathrm{~cm}^{2}$ also did not find the ulcer size was a risk factor for non-healing. This is consistent with Milic's[37] 52 weeks prospective study that showed that there is no association between the ulceration surface and the failure of venous leg ulcers to heal.
In our study, 8 out of 12 ulcers were between 30 and $450 \mathrm{~cm} 2$. VEGF content in patient sera seems to be consistent with the results previously described, supporting the hypothesis of a non-dependence between healing potential and the size, for ulcers of large areas. To confirm this differential behaviour of ulcer prognosis with size it would be necessary to carry out an exhaustive study, increasing the number of patients, and taking into account the serum factors and the risk factors identified so far. It would be desirable to carry an analysis of wound size in a continuous way. This would give a curve summarizing the behavior of the non-healing risk throughout the whole studied size range, without fixing an arbitrary cut-off point for the analysis. While there are many risk factors involved in the healing potential of the ulcer, the effort to identify one major factor would help to define the therapeutic. In this sense, the size of the ulcer is still relevant.

\section{CONCLUSION}

Within this pilot study, ulcer size did not influence the characteristics of sera from $\mathrm{CW}$ patients. The systemic effect of chronic ulcer detained in the inflammatory phase is evidenced through the following characteristics of patient serum: 1) presence of VEGF-165; 2) lack of bFGF; 3) presence of cell proliferation; and 4) absence of collagen deposition promotion.

\section{ACKNOWLEDGMENTS}

We wish to thank the patients who made this study possible. This work was partially supported by a research grant provided by Universidad AbiertaInteramericana (Interamerican Open University), Buenos Aires, Argentina.

\section{REFERENCES}

[1] Nettel F, Rodríguez N, NigroJ, et al. Primer consenso latinoamericano de úlceras venosas Resumen. Flebología y linfología - Lecturas vasculares.2013;8(21);1284-1315

[2] Grey J, Enoch S, Harding K. ABC of wound healing venous and arterial leg ulcers. $B M J$. 2006;332;347-350

[3] Eming SA, Krieg T, Davidson JM. Inflammation in Wound Repair: Molecular and Cellular Mechanisms. J Invest Dermatol. 2007; 127;514-525

[4] Rodier F, Campisi J. Four faces of cellular senescence. J Cell Biol. 2011;192(4); 547-556

[5] Shoab SS, Scurr JH, Coleridge-Smith PD. Increased plasma vascular endothelial growth factor among patients with chronic venous disease. J Vasc Surg.1998;28(3);535-540 
[6] Bao P, Kodra A, Tomic-Canic M,et al. The role of vascular endothelial growth factor in wound healing. J Surg Res.2009;153(2);347-358

[7] Werner S, Krieg T, Smola H. Keratinocytefibroblast interactions in wound healing. $J$ Invest Dermatol. 2007;127;998-1008

[8] Chung JH, Seo JY, Choi HR, et al.Modulation of skin collagen metabolism in aged and photoaged human skin in vivo. $J$ Invest Dermatol.2001;117;1218-1224

[9] Mosmann T. Rapid colorimetric assay for cellular growth and survival: application to proliferation and cytotoxicity assays. J Immunol Methods. 1983;16;65(1-2); 55-63

[10] Development Core Team. R: A language and environment for statistical computing. Vienna, Austria: R Foundation for Statistical Computing; 2011. URL http://www.r-project. org

[11] Martin P. Wound healing - aiming for perfect skin regeneration. Science. 1997;27;75-81

[12] Peng C, He Q, Luo C. Lack of keratinocyte growth factor retards angiogenesis in cutaneous wounds. J Int Med Res. 2011;39;416-423

[13] Lauer G, Sollberg S, Cole M, et al. Expression and proteolysis of vascular endothelial growth factor is increased in chronic wounds.J Invest Dermatol. 2000;115(1);12-8

[14] Drinkwater SL, Burnand KG, Ding R, Smith A. Increased but ineffectual angiogenic drive in nonhealing venous leg ulcers. $J$ Vasc Surg.2003;38; 1106-1112

[15] Smith RK, Golledge J.A systematic review of circulating markers in primary chronic venous insufficiency. Phlebology. 2014;29(9); 570-579

[16] Shoab SS, Scurr JH, Coleridge-Smith PD. Plasma VEGF as a marker of therapy in patients with chronic venous disease treated with oral micronised flavonoid fraction - a pilot study. Eur J VascEndovasc Surg. 1999;18; 334338

[17] HowladerMH, Smith PDC. Relationship of plasma vascular endothelial growth factor to CEAP clinical stage and symptoms in patients with chronic venous disease.Eur $J$ VascEndovasc Surg. 2004; 27(1);89-93

[18] Gohel MS, Windhaber RA, Tarlton JF, et al. The relationship between cytokine concentrations and wound healing in chronic venous ulceration.J VascSurg. 2008;48(5); 1272-1277

[19] Bermúdez S, Herrera M, Hochman A, et al. Consenso sobre cicatrización de heridas. Dermatología Argentina.2008;14(4);1-41

[20] Falanga V. The chronic wound: impaired healing and solutions in the context ofwound bed preparation. Blood Cells Mol Dis.2004; 32;88-94
[21] Varani J, Spearman D, Perone P, et al. Inhibition of type I procollagen synthesis by damaged collagen in photoaged skin and by collagenase-degraded collagen in vitro. Am J Pathol.2001;158; 931-942

[22] Varani J, Schuger L, Dame MK, et al. Reduced fibroblast interaction with intact collagen as a mechanism for depressed collagen synthesis in photodamaged skin. J Invest Dermatol.2004; 122;1471-1479

[23] Quan T, Little E, Quan H, et al. Elevated matrix metalloproteinases and collagen fragmentation in photo damaged human skin: impact of altered extra cellular matrix micro environment on dermal fibroblast function. $J$ Invest Dermatol.2013;133(5);1362-1366

[24] Dimri GP, Lee X, BasileG, et al.A biomarker that identifies senescent human cells in culture and in aging skin in vivo.Proc Natl AcadSci USA. 1995;92;9363-9367

[25] Stanley A, Osler T. Senescence and the healing rates of venous ulcers. J Vasc Surg.2001; 33;1206-1211

[26] Wall IB, Moseley R, Baird DM, et al. Fibroblast dysfunction is a key factor in the non-healing of chronic venous leg ulcers.J Invest Dermatol.2008;128; 2526-2540

[27] Van Linthout S, Miteva K, Tschope C. Crosstalk between fibroblasts and inflammatory cells. Cardiovasc Res. 2014; 102;258-269

[28] Harding KG, Moore K, Phillips TJ. Wound chronicity and fibroblast senescence: implications for treatment. Int Wound J.2005; 2(4);364-368

[29] Lindahl GE, Chambers RC,Papakrivopoulou J, et al. Activation of fibroblast procollagen $\alpha 1$ (I) transcription by mechanical strain is transforming growth factor- $\beta$-dependent and involves increased binding of ccaat-binding factor $(\mathrm{CBF} / \mathrm{NF}-\mathrm{Y})$ at the proximal promoter. $J$ Biol Chem.2002;277;6153-6161

[30] Cowin AJ, Hatzirodos N, Holding CA, et al. Effect of healing on the expression of transforming growth factor beta(s) and their receptors in chronic venous leg ulcers. $J$ Invest Dermatol.2001;117;1282-1289

[31] Pastar I,Stojadinovic O, Krzyzanowska A. Attenuation of the transforming growth factor signaling pathway in chronic venous ulcers. Mol Med.2010;16(3-4);92-101

[32] Higley HR, Ksander GA, Gerhardt CO, Falanga V. Extravasation of macromolecules and possible trapping of transforming growth factor-beta in venous ulceration. $\mathrm{Br} J$ Dermatol.1995;132(1);79-85

[33] Shah MJ, Omar E, Pai DR, Sood S. Cellular events and biomarkers of wound healing. Indian J Plast Surg.2012; 45(2); 220-228 
[34] Labropoulos N, Wang ED, Lanier ST, Khan SU. Factors associated with poor healing and recurrence of venous ulceration. PlastReconstr Surg. 2012; 129; 179-186

[35] Scotton MF, Miot HA, FernandesAbbade LP. Factors that influence healing of chronic venous leg ulcers: a retrospective cohort. $A n$ Bras Dermatol. 2014;89(3);414-422

[36] Minimas DA. Ageing and its influence on wound healing. Wounds UK.2007;3(1);42-50

[37] Milic DJ, Zivic SS, Bogdanovic DC, et al. Risk factors related to the failure of venous leg ulcers to heal with compression treatment.J Vasc Surg.2009;49(5);1242-1247

[38] Kucukguven A, KhalilRA. Matrix metalloproteinases as potential targets in the venous dilation associated with varicose veins. Curr Drug Targets. 2013;14(3);287-324

[39] Franks PJ, Bosanquet N, Connolly M, et al. Factors associated with healing leg ulceration with high compression. Age Ageing. 1995;24;407-410

[40] Margolis DJ, BerlinJA, StromBL,Risk factors associated with the failure of a venous leg ulcer to heal Arch Dermatol. 1999;135(8);920-926

Citation: Melisa C Crocco, Diana M Kelmansky, Roberto H Mengarelli, Roberto Cherjovsky, Alicia G Fuchs. Can venous ulcer size be associated with the healing potential of serum? Pilot study. ARC Journal of Dermatology. 2017; 2(2): 9-15. doi:dx.doi.org/10.20431/2456-0022.0202003.

Copyright: (C) 2017 Authors. This is an open-access article distributed under the terms of the Creative Commons Attribution License, which permits unrestricted use, distribution, and reproduction in any medium, provided the original author and source are credited. 